\title{
THE EVALUATION OF FACTORS OF BUSINESS PERFORMANCE ON MICRO-LEVEL
}

\author{
Chazov Ye.V. \\ Zaporizhia National University \\ Ukraine, 69600, street Zhukovsky, 66, Zaporizhia \\ zhenyavarenya@gmail.com
}

Key words:

efficiency factors, criteria, economic effect, efficiency analysis, forms of efficiency, ratios, performance evaluation ratios, level of management.
The article considers the issues of assessing the economic efficiency of enterprises. The problem of measuring the effectiveness of the organization is considered. The author considers the performance indicators of the enterprise at 3 levels: economic, sectoral, domestic. At each level, the author considers efficiency in terms of impact and significance for, respectively, enterprises, industries and economic systems. On this basis, the indicators of measuring the economic efficiency of economic entities are systematized. The main tasks of the analysis of efficiency of economic activity of the enterprises are defined. Modern approaches to its evaluation are studied. The author proposes a classification of factors influencing the efficiency of entrepreneurship.

\section{ОЦІНКА ФАКТОРІВ ДІЯЛЬНОСТІ БІЗНЕСУ НА МІКРО-РІВНІ}

\author{
Чазов С.B. \\ Запорізький національний університет \\ Украӥна, 69600, м. Запоріжжя, вул. Жуковського, 66
}

\begin{abstract}
Ключові слова:
коефіцієнти ефективності, критерії, економічний ефект, аналіз ефективності, форми ефективності, коефіцієнти, коефіцієнти оцінки ефективності, рівень управління.
\end{abstract}

У статті розглядаються питання оцінки економічної ефективності підприємств. Розглянуто проблему вимірювання ефективності організації. Автор розглядає показники діяльності підприємства на 3 рівнях: економічному, галузевому, внутрішньому. На кожному рівні автор розглядає ефективність 3 точки зору впливу та значущості для підприємств, галузей та економічних систем. На цій основі систематизовано показники вимірювання економічної ефективності суб' єктів господарювання. Визначено основні завдання аналізу ефективності господарської діяльності підприємств. Вивчено сучасні підходи до його оцінки. Автор пропонує класифікацію факторів, що впливають на ефективність підприємництва.

\section{Analysis of recent research and publications}

Issues of developing a classification of factors influencing the economic efficiency of enterprises have always been in the spotlight of economists, in particular Voloshin D., Ganarsky V. Goldstein D., Kozlova I., and others in which the authors provide approaches to assessing the effectiveness of the enterprise through the factors influencing the performance indicators. However, there is still no perfect system of factors of influence and a comprehensive assessment of the economic efficiency of enterprises.

\section{The main material of the research}

Depending on the level of management, efficiency factors can be divided into three groups: economic, sectoral, domestic. In turn, each of the areas of efficiency is detailed in relation to the level of management and specific stages of development of the system of relations.
The problem of measuring the effectiveness of the organization should be considered with the following aspects [1]:

- criterion of management efficiency; key evaluation principle

- efficiency;

- indicator (system of indicators) of efficiency;

- methods of calculating the efficiency of management;

- organizational measures for the introduction of a new evaluation system in

- practice.

Criteria reflect the essence of efficiency, indicators serve as a means of measuring and comparing efficiency in accordance with its criteria.

Efficiency in a broad sense characterizes the qualitative side of the development of the enterprise system, showing 
which combination of resources the final result. Quantitatively, efficiency is expressed through the ratio between the results obtained in the production process and the cost of social labor associated with achieving these results. Therefore, the meaning of increasing production efficiency is a faster growth of the result (effect) compared to costs, resulting in a unit of effect is less social work [2].

The criterion of the efficiency of social production can be considered in two ways: as achieving the maximum effect of each unit of social labor costs or as achieving a minimum of these costs per unit of effect.

A generalized efficiency indicator, constructed on the basis of this criterion, unambiguously assesses the efficiency of production at a certain point in time. It must take into account all the factors that affect the efficiency of production, which provides a comprehensive assessment. Such a generalizing indicator may be the ratio of economic result to total costs (current and capital), required for its production. The generalizing indicator is used at definition of efficiency both for all national economy, and its separate branches, and also at definition of efficiency of capital investments and new technics.

Accordingly, the indicator of measuring the efficiency of the national economy is the ratio of national income and applied production assets; to measure the efficiency of capital investment - the ratio of profit and capital expenditures.

Currently, the most complete and consistent study of economic efficiency of economic activity is given in the theory of integrated economic analysis, where efficiency is devoted to sections of prospective, current and operational analysis, which evaluates the efficiency of economic activity, identifies factors of change, untapped opportunities and reserves.

Analysis of the overall efficiency of economic activity of the enterprise is the prerogative of senior management and is associated with determining the price of the product, the size of the batch of raw materials or supplies, replacement of equipment or technology. Other decisions must also be evaluated in terms of the overall success of the firm, the nature of its economic growth and efficiency.

The main tasks of efficiency analysis: assessment of the economic situation; identification of factors and causes of the achieved state; Preparation and justification of management decisions; identification and mobilization of reserves to increase the efficiency of economic activity. One of the priority areas of analysis is to identify extensive and intensive factors that change efficiency [2].

In this case, extensive factors are associated with an increase in production due to quantitative factors of economic growth: additional labor, expansion of retail space, construction of a new facility, etc. On the contrary, intensive factors are associated with the use of qualitative factors of economic growth and are characterized by the degree of return of each of the resources used. The quantitative ratio of these factors is expressed in the indicators of the use of production and financial resources.

The volume of production in value terms is a function or result of the impact of the use of all types of resources. Since the production process is carried out only in the presence of all elements of the labor process in their relationship, to identify the impact of these factors on production results is impossible.
Each indicator of resource use, in turn, consists of the action of factors of the following orders. For example, labor productivity depends on the duration of working time, as well as on the load during working hours and productive labor, which is determined by organizational, technical and other (natural and social) conditions of production.

The goals of the subjects of efficiency analysis may be different, but they all converge in the main - the desire to obtain key parameters that allow to give an accurate assessment of both the current state of the object and the prospects for its development. If the interest of the enterprise in the Soviet period was determined by the plan, then in market conditions it is necessary to take into account and coordinate the interests of various subjects of competitive interaction, interested in private results.

At the present stage of development of society, it is necessary to reconsider estimates of the most important factors of increase of efficiency of production taking into account conditions of market economy. To this end, a consolidated classification of performance factors should be developed. Here are the basic principles of its construction.

Depending on the direction of action, all factors are divided into internal and external [3].

Internal factors can be grouped into the following groups, related to the personality of the leader and the ability of his team to manage the company in market conditions; acceleration of STP, innovation policy of the enterprise; improving the organization of production and labor, enterprise management; organizational and legal form of management; creating a favorable socio-psychological climate in the team; specifics of production and industry; product quality, its competitiveness, cost management and pricing policy; depreciation and investment policy.

The efficiency of the enterprise in market conditions largely depends on external factors, which can be classified into the following groups due to the dynamics of domestic and world markets, which is manifested in changes in supply and demand, as well as price fluctuations; changing the political situation both within the country and on a more global scale; inflationary processes; activities of the state.

Along with the general decisive factors for improving production efficiency, for enterprises now, in our opinion, are relevant progress in science and technology, improving the quality of products and achieving high social results.

Classification by main directions of development and improvement of production reflects the effectiveness of the use of costs and resources and includes the following factors: the system of state regulation of the structure of production; improving the sectoral and territorial organization of production through the development of concentration, specialization, cooperation and combination; raising the cultural, technical and qualification level of production staff.

Depending on the place of implementation of efficiency factors, they are divided into domestic, sectoral and economic, through which the savings of social labor in terms of individual parts of production management [4]. The factors of this group at the enterprise level include organizational and technical and socio-economic (acceleration of scientific and technological progress, improvement of the organization of production, labor and management, etc.). 
In the new economic conditions there is a need for a deeper understanding of the meaning of the concept of efficiency. The level of production efficiency reflects not only the ratio of results and costs, but also the degree of use of economic potential.

As a rule, the production capacity of a society or enterprise means the volume of output. However, no less important are the costs of its production. Therefore, the economic potential of the enterprise can be defined as its ability to produce and sell a certain amount of quality products with full and rational use of available resources and make a profit.

There are general and comparative efficiency of labor costs. Both overall and comparative efficiencies are relative values - the ratio of the effect to the cost that caused it. The overall efficiency, in particular, can be calculated for each object of capital investment and new equipment separately. It characterizes the total amount of return (effect), which results from the implementation of costs. Comparative efficiency is calculated by choosing one of two or more options for solving a particular production and economic problem. It characterizes the economic advantages of one option over others.

Calculations of the overall efficiency should be carried out in the planning process to characterize the effect that will be obtained as a result of allocated capital investments, as well as to assess the actual economic efficiency of the costs already incurred. Calculations of comparative economic efficiency are made at the stages of planning and design of objects when comparing possible options for their implementation. Once the option is selected, you can determine its overall effectiveness. The value of the overall efficiency depends on the feasibility of the option selected when calculating the comparative efficiency.

Depending on the nature of the labor process, production efficiency can take the form of technical and economic and socio-economic efficiency. Technical and economic aspects of efficiency characterize the development of the main factors of production and the effectiveness of their use. Social efficiency solves specific social problems (for example, improving working conditions, environmental protection, quality of life, etc.). Usually social results are closely linked with economic ones, because the basis of any progress is the development of material production.

Regarding the areas of application, it is advisable to distinguish such forms of efficiency as local and private. Local efficiency is determined in terms of individual parts of the economy (enterprise, industrial complex, industry, region). Private efficiency reflects the effectiveness of the use in the production process of certain types of costs and resources (labor, fixed and working capital).

The following forms of efficiency differ according to the objects of definition: current production; technical re-equipment, reconstruction, expansion and new construction; capital investments and new equipment; foreign economic activity; environmental protection, etc.

The main indicators of production efficiency are labor productivity; capital intensity of a unit of production; return on fixed assets; material consumption per unit of output; the ratio of such indicators as gross domestic product, national income, etc.
The system-wide criterion permeates all lower levels of government, the goals of which, in terms of system-wide interests, are presented as a means of achieving system-wide goals. Given the above, consider the resources and results at the level of a particular manufacturer. Resource elements at the input of this subsystem are presented as fixed assets and working capital, labor of employees, capital and entrepreneurial skills of managers (managers), information resources and technologies. In a generalized form, the resources used by the enterprise take the form of production costs.

The local goal of the producer, of course, is profit. Therefore, as a local criterion of efficiency is the ratio of profit to cost of production, ie the traditional indicator of profitability. But, in terms of system-wide purpose, the role, purpose of the manufacturer is to produce a set (range) of products of a certain quality and quantity and in a given time interval.

Therefore, from a system point of view, the efficiency of any producer (enterprise, organization) should be measured by its contribution to the system-wide result. This is where the dual approach to performance evaluation can be found:

a) the economic efficiency of this subsystem in terms of contribution to the system-wide criterion;

b) economic efficiency by local criteria.

Enterprises of all sectors of the national economy must ensure the achievement of maximum economic results with optimal economic potential, relative reduction of production and circulation costs, high quality work. Therefore, economic efficiency must be studied systematically. The system of its research should include indicators for assessing the rational use of funds for wages and other maintenance costs of the enterprise, long-term, intangible, current (current) assets, productivity, return on assets, profitability and others.

The economic efficiency of commercial activity should be assessed by economic results, which characterizes the work of the enterprise as a whole: generalizing economic indicators (turnover, costs, profits, prices); indicators of resource use (production, turnover); quality of trade service (breadth, stability and updatability of the range); quality of goods.

\section{Conclusions}

Generalization of scientific results of a number of leading researchers, such as D.V. Goldstein [3], VV Ganarsky [2], IS Kozlov [4], allows us to develop the following classification of factors influencing the level of production costs and results of economic activity, and, consequently, the size of the efficiency of entrepreneurial activity:

1. Technical factors that reflect the use of advanced equipment, its timely update; improvement of the technical base of transportation and storage of raw materials; creation of an experimental base for modeling resource consumption, etc.

2. Organizational factors that reflect the improvement of the organization of accounting for the receipt and use of resources; reduction of the production cycle from obtaining resources to the output of finished products; development of infrastructure and improvement of quality of repair of technological equipment; improving the organization of 
production and labor in order to save raw materials; organization of secondary use of by-products; development and implementation of organizational and technical measures to save resources; improving the structure of products.

3. Economic factors that operate in the field of the law of scale of production and the law of saving time. They involve the use of scientific management approaches in resource management; use of methods of functional-cost analysis, forecasting, economic-mathematical methods; reduction of unit costs [6].

It is known that the growth of production can be achieved by expanding the market and improving the structure of products. With increasing scale of production there is an opportunity to apply economic resource-saving technologies, to reduce losses of material resources and to increase thereby efficiency of production. Studies show that by increasing the scale of production it is possible to reduce the cost of production up to 3 times, increase its quality by up to $40 \%$, but this will increase consumer costs by reducing the parametric range and underutilization.

4. Social factors involve the use of best practices in the use of resources, improving working conditions and recreation of employees, the use of incentives and responsibility for savings, the implementation of socio-psychological measures to save, staff training.

The implementation of efficiency factors should be aimed at achieving an optimal balance between costs and performance, which has a positive impact on production and financial performance, sustainable development of enterprises and increase their competitive position in the market environment, and therefore necessitates the development of a system of indicators.

1. Voloshin D. Efficiency of economic activity. Audit information. 2019. № 9. pp. 27-32.

2. Ganarsky V. Models of improving the efficiency of the company. Financial newspaper. Regional issue. 2018. № 20. pp. 12-13.

3. Goldstein D. Economic efficiency of interproduction cooperation: social aspects. Saratov : Izd-vo SGTU, 2018. 168 p.

4. Kozlov I. Effective enterprise management systems: success factors. Financial newspaper. Regional issue. 2018. № 22. S. 8.

5. Financial and credit encyclopedic dictionary / under the general. ed. A.G. Gryaznova. Moscow : Finance and Statistics, 2016. 1168 p.

6. Economic and legal dictionary / ed. A.N. Azriliana. Moscow : Institute of New Economy, 2014. 1088 p. 